\section{Britain wins first big contracts}

BRITAIN has become the first foreign country to win a substantial contract for research in the US Strategic Defense Initiative (SDI). On Tuesday last week. George Younger, the Secretary of State for Defence, and Caspar Weinberger, his opposite number in the United States, signed a $\$ 10$ million letter of offer and acceptance in Washington. A further $\$ 4.3$ million contract goes to the United Kingdom Atomic Energy Authority's Culham Laboratory.

The contracts come at a time when there had been increasing criticism of British failure to obtain funds for research in the SDI programme. As Britain was the first country to back the US "star wars" project and to agree to cooperate on research and development, there were hopes that major contracts would be won — $£ 1,000$ million was announced as a possible figure last year by the then Secretary of State for Defence, Michael Heseltine. But there is now little hope that expenditure in Britain will come anywhere near this target.

The $\$ 10$ million contract is for a theoretical research study, expected to last 22 months, of the systems "necessary for the integrated defence of Europe". At present, that means the study will give a British view of the defence of Europe; at a later date, European allies may be added to the project. The contract has been put out to tender.

Culham Laboratory's contract is to cover research on neutral-beam particle systems. Neutral-beam weapons could form part of the first layer of an SDI system, shooting down ballistic missiles from space-based platforms. The Culham group, headed by Dr Tom Green, has already built up an international reputation for neutral-beam research. In collaboration with a French group, it designed the neutral-beam injectors for the Joint European Torus (JET) which sits alongside the Culham laboratories. The injectors fire intense beams of very energetic hydrogen and deuterium atoms into the tokamak to help heat up the plasma inside it. To generate the beam, positively-charged ions are accelerated electrostatically; they are subsequently neutralized in a gas cell, as charged particles would not be able to penetrate the intense magnetic field confining the plasma. Neutral beams are also essential for a space-based weapon as charged particles would be sent off course by the Earth's magnetic field. But for SDI application, where very high-energy beams are needed, negatively charged ions will be accelerated and an electron stripped off them before firing - it is here that the Culham group will have to develop new technology.
Any application for neutral beams as weapons is, of course, a long way off. Much basic research remains to be done. But if the present work, to extend over a three-year period, is successful, further SDI contracts may come along. The Culham group has already proved itself to be imaginative in finding research contracts; since the JET work drew to a close it has carried out research on semiconductor ion implantation, tokamak plasma beam diagnostics and ion thruster engines for keeping geostationary satellites on station.

Other SDI projects are rumoured to be in the pipeline for British research groups. The United States is interested in work on electromagnetic guns carried out at the

\section{Washington}

ELEVEN US senators have signed a letter to President Reagan urging him to give his personal support to the Superconducting Supercollider (SSC), the $40 \mathrm{TeV}$ protonproton collider now at the design stage. Without strong White House support, the senators say the project "cannot go forward".

Already there are rumblings in Congress that the Challenger accident and the Gramm-Rudman deficit reduction act will make it hard to find the $\$ 3,010$ million needed to build SSC. The Department of Energy (DoE) steadfastly maintains that it has not decided SSC's future, but construction delays seem likely, and it is just possible that the project may be cancelled.

Senators Barry Goldwater and Dennis DeConcini, both Republicans from Arizona, organized the letter to President Reagan. While the letter describes SSC as "a very important national science project", the senators also find SSC attractive for the 7,000-8,000 jobs and millions of construction dollars it will bring to the state where it is built.

In testimony last week before the Senate Committee on Energy and Natural Resources, Alvin Trivelpiece, director of DoE's Office of Energy Research, called technical progress on SSC "excellent". But Trivelpiece said DoE is still weighing its options. A decision must be made soon so that the department's budget can reach the White House by September. Members of Congress in both the House and Senate feel a full-scale start for SSC in the 1988 budget is unlikely.

The House Appropriations Committee last month removed from the DoE budget request $\$ 20$ million that was to be used for continued development of SSC. While the committee's action must still be approved
Royal Armament Research and Development Establishment and it is likely that a contract will be signed in the coming months.

Electromagnetic guns come in two varieties. In a rail gun two rails are bridged by an armature behind a metal projectile. When a current of several million amps is applied the expanding current loop fires the projectile.

Other electromagnetic guns are more similar to a linear induction motor: a series of switched coils induces a current in the projectile to fire it.

Either way velocities in the tens of kilo metres per second can be achieved - a standard army rifle bullet goes at less than a kilometre a second. The aim is for velocities of $50-100 \mathrm{~km}$ per sec for electromagnetic guns which might be based in space or on land.

Alun Anderson

\title{
Supercollider in the balance
}

by the full House, and later by the Senate. it was a signal that Congress is not interested in seeing more money put into SSC until its future is determined.

In May, DoE completed a favourable review of the conceptual design of SSC. The review described the $\$ 3,010$ million budget proposed for SSC as "credible and consistent with the scope of the project". The report also called the six-and-a-halfyear construction schedule feasible, and said SSC will meet the requirements of high-energy physics "well into the next century".

But SSC's timing may be bad. William Graham still awaits confirmation by the Senate as director of the White House Office of Science and Technology Policy (OSTP). Until he comes on board as director, nobody at OSTP is anxious to carry the torch for such an ambitious project. The retirement of Hugh Loweth from the Office of Management and Budget, after 13 years as head of the Energy and Science Division. may also influence reception of the budget.

Senator Daniel Evans (Republican. Washington), a member of the Senate Energy and Natural Resources Committee, has declined to sign the GoldwaterDe Concini letter because he feels it would be irresponsible to commit funds to SSC when Congress is trying desperately to reduce the budget deficit. But he does have a modest proposal for DoE. Evans wants DoE to offer SSC as a "carrot" to the state it chooses for the site of the first deep geological repository for high-level nuclear waste. The three states chosen by DoE as final candidates for the waste storage site. Washington, Texas and Nevada. have so far been less than enthusiastic. All three have gone to court to try to block DoE's plans. 